\title{
Na defesa dos sagrados interesses: a greve dos ferroviários no sul da Bahia (Ilhéus e Itabuna, maio de 1927)
}

\author{
In defense of sacred interests: the railroad workers strikes in South Bahia \\ (Ilhéus and Itabuna, May 1927)
}

\section{Philipe Murillo Santana de Carvalho*}

Resumo: O principal objetivo deste artigo é analisar a greve, ocorrida em 1927, dos ferroviários da Estrada de Ferro que ligava Ilhéus a Conquista. A paralisação dos ferroviários foi uma das principais mobilizações operárias do sul da Bahia na Primeira República, com a atuação de diversas agremiações proletárias de llhéus e de Itabuna em torno das atividades e da agenda na "defesa dos sagrados interesses". Com contornos pacíficos e atuando nas brechas da política oligárquica, os ferroviários deram dimensões populares à greve, de modo a pressionar intendentes, parlamentares e associações patronais, utilizando-se do nacionalismo brasileiro contra os administradores ingleses da ferrovia. $\mathrm{O}$ artigo foi escrito a partir de matérias veiculadas em jornais, de relatórios institucionais e de correspondências coletadas em arquivos da Bahia e do Rio de Janeiro.

Palavras-chave: Ferroviários; Greve; Sul da Bahia; Ilhéus.

Abstract: The main objective this article is to analyze the railroad workers strikes of the State of Bahia South-western Railway Co. Ltd.in 1927. The railroad workers strikes were one of the principal worker's campaign in South Bahia during First Republic, with mobilization much working-class associations of Ilhéus and Itabuna city around of the activities and the schedule "in defense of sacred interests". Of pacific way and acting inside of the oligarchic Politic, the railroad workers turn up popularity strikes, so that press over mayor, parliamentarians and patronal associations, and use themselves of the Brazilian nationalism against the English chiefs of the railway company. This article was writing from newspaper, institutionals reports and correspondence researched at archives from Bahia and Rio de Janeiro.

Keywords: Railroad workers; Strikes; Bahia; Ilhéus.

Docente do Instituto Federal da Bahia - campus Ilhéus. Doutor em História Social, pela Universidade Federal da Bahia (UFBA). ORCID: https://orcid.org/0000-0003-4242-5990. E-mail. philipe@ifba.edu.br. 
Até onde se sabe, o sul da Bahia presenciou poucas greves nos anos 1920. Do que foi possível levantar, foram apenas duas paralisações, que ocorreram exatamente na Estrada de Ferro Ilhéus-Conquista (EFIC), conhecida também por State, alcunha derivada do nome inglês da companhia: The State of Bahia South-western Railway Co. Ltd. Em 1924, os carroceiros cruzaram os braços em função das determinações impostas pela administração da companhia ferroviária sobre a atividade de carga e descarga dos produtos transportados. No dia 2 de janeiro daquele ano, o superintendente Francis Reginald Hull baixou uma portaria alterando o procedimento de carga e descarga de mercadorias dos trens da companhia. Entre as medidas, estabeleceu-se que as encomendas para o distrito de Água Preta (atual município de Uruçuca, Bahia) fossem despachadas somente às segundas, quartas e sextas-feiras, e para a localidade de Sequeiro de Espinho, apenas às terças, quintas e sábados. Também foi determinado que as mercadorias fossem recebidas pelos funcionários da Estrada de Ferro quando estivessem com nota de expedição, contendo a quantidade e a natureza da mercadoria levada. Caso houvesse mais de uma carroça no transporte do frete, deveria haver dois documentos de expedição, sendo que o próprio carroceiro deveria levar à balança as mercadorias a serem pesadas. ${ }^{1}$

Na prática, além de limitar os dias de atuação dos carroceiros, a administração da ferrovia estabeleceu novas exigências para o despacho de mercadorias, o que refletiu sensivelmente no aumento da carga de trabalho sem reajuste salarial. Após a publicação da portaria, os carroceiros insatisfeitos paralisaram as atividades e se organizaram para contestar a medida da State. Não sabemos ao certo em que dia os trabalhadores decidiram pela paralisação, pois as poucas notícias sobre o episódio foram publicadas apenas no dia 8 de janeiro, quando o semanal Correio de llhéus, órgão noticioso ligado à família do prefeito Mário Pessoa e simpático aos chefes da companhia ferroviária, voltou a funcionar após as festas de ano novo de 1924. O certo é que, naquele mesmo dia 8 , houve uma assembleia da categoria na sede da Sociedade União dos Estivadores para a qual estavam convidados os carroceiros e os patrões. $^{2}$

No encontro, os carroceiros em greve pautaram suas discussões em torno da necessidade de aumento das remunerações e da instalação de uma sociedade denominada União dos Condutores de Veículos. Nesse sentido, foi eleita uma

\footnotetext{
Correio de Ilhéus, Ilhéus, 8 jan. 1924, ano IV, n. 391, p. 2. Arquivo Público Municipal de Ilhéus João Mangabeira (APMIJM).

2 Ibidem, p. 2.
} 
diretoria, ${ }^{3}$ responsável por levar aos negociantes a proposta de preço das carroçadas cujos valores para os fretes urbanos seriam de $1 \$ 500$ em imóveis térreos e $2 \$ 000$ em prédios de andares superiores. As fontes também dão conta de que alguns comerciantes se prontificaram a um acordo em que a nova tabela da carretagem seria de $1 \$ 200$ para casas térreas e de $1 \$ 500$ com piso superior. Infelizmente, a documentação disponível não informa o efeito de tal atitude. ${ }^{4}$ De todo modo, ao fazer greve na Estrada de Ferro Ilhéus-Conquista, os carroceiros atingiram um instrumento central do capitalismo agroexportador da Bahia no início do século XX.

Em 1927, outra greve obteve uma repercussão bem maior do que a dos carroceiros. Durante uma semana de maio daquele ano, os ferroviários da Estrada de Ferro Ilhéus-Conquista cruzaram os braços, alinhando-se com os movimentos paredistas das demais companhias de trem da Bahia. Com atos populares e discursos de apelo ao trabalhador nacional, a paralisação comprometeu o funcionamento da economia do sul do estado que utilizava os vagões da empresa britânica para deslocar sua produção de cacau rumo ao porto de Ilhéus. Diante do impasse, os grevistas se utilizaram das suas relações com lideranças oligárquicas regionais, prefeitos e parlamentares para reverter o quadro de negociações em seu favor frente aos chefes da companhia.

Diante desse cenário, o objetivo deste artigo é analisar a greve ferroviária de 1927 a partir da capacidade do movimento paredista de interpor seus interesses diante dos patrões nas brechas das relações políticas oligárquicas do sul da Bahia.

\section{A The State nas terras do cacau}

Os trilhos das ferrovias chegaram tardiamente ao Sul da Bahia, se comparamos com as obras de construção iniciadas no século XIX no Recôncavo baiano e no norte do estado. Para se ter uma ideia, a construção da Estrada de Ferro Bahia-São Francisco foi iniciada na década de 1850, cujo projeto previa ligar Salvador a Juazeiro. ${ }^{5}$ A proposta de expandir a malha ferroviária ligando o porto de llhéus a Vitória da Conquista surgiu depois de 1903 para contemplar as necessidades da economia agroexportadora do cacau. Foram realizados levantamentos e estudos

3 Composta por Artur Guedes Chagas (presidente), Príamos José de Lemos (tesoureiro), José Rosário da Silva (secretário) e Antonio Mendes dos Santos (procurador).

4 Correio de Ilhéus, Ilhéus, 10 jan. 1924, ano IV, n. 392, p. 1. APMIJM.

5 Há vários trabalhos sobre história das ferrovias baianas. Destacarei as contribuições de ZORZO, Francisco Antonio. Ferrovia e rede urbana na Bahia. Feira de Santana: Ed. da UEFS, 2001; e SOUZA, Robério S. Tudo pelo trabalho livre: trabalhadores e conflitos no pós-abolição (Bahia, 1892-1909). Salvador: EDUFBA, 2011. 
preliminares para viabilizar a construção. O decreto autorizando as obras pela empresa Oliveira, Carvalho \& Cia, pertencente à Bento Berilo de Oliveira, foi concedido em 1904. Para Manoel Tenório Júnior, a chegada dos "tentáculos ferroviários" foi um "marco divisório para a região cacaueira, pois além de transportar cargas ...foi um importante meio rápido de locomoção de pessoas, alterando completamente a sensação prévia existente entre tempo e espaço". ${ }^{6}$

A construção da ferrovia foi financiada pelo capital inglês e, por isso, a empresa foi denominada The State of Bahia South-western Railway Co. Ltd. Popularmente ela ficou conhecida pelo diminutivo State. Em obra publicada pelo inglês Reginald Lloyd em 1913, ele relatou as dificuldades com os elevados custos para finalização das obras, apesar de cortar uma "zona fértil e rica". Os acidentes topográficos e as precauções contra as enchentes exigiram a edificação de aproximadamente 200 pontes. Lloyd ainda sublinhou outro elemento que elevou os valores das obras: "contar com [uma] mão de obra que não só foi muito cara, como também pouco hábil". ${ }^{7}$ As queixas talvez indiquem as dificuldades dos chefes de obras para disciplinar os operários. Durante sua construção, os garimpeiros, como eram conhecidos os trabalhadores da obra, entraram em diversos conflitos com os engenheiros. Havia reclamações sobre a indisposição de homens para o serviço e a indisciplina frequente. Relatava-se que os operários eram movidos "pela desordem, a falta de educação, o gosto das arruaças e a ostentação da valentia, sentimentos comuns a esses ajuntamentos de gente atrasada" [grifos nossos]. Outra informação é que vinham "de muito longe, desde o início da linha férrea, essas alterações da ordem emanadas da índole desordeira de trabalhadores da construção". ${ }^{8}$ As narrativas sobre a "valentia" da "gente atrasada" podem relatar a respeito dos estereótipos que recaíam sobre os trabalhadores humildes que reagiam ao controle e às hierarquias sociais na construção dos trilhos da State.

O empreendimento da Estrada de Ferro movia o interesse de muita gente poderosa do Brasil e da Inglaterra. Em sua primeira etapa, a ferrovia conectou as principais zonas produtoras de cacau do sul da Bahia na Primeira República, que se concentravam no eixo Ilhéus-Itabuna, delineado pelo trajeto do rio Almada ao rio Cachoeira. Em 1928, a segunda etapa da ferrovia se estendeu em direção ao norte

6 AZEVEDO JÚNIOR, Manoel Ursino T. Os caminhos de ferro: a história da ferrovia na região cacaueira da Bahia. Itabuna, BA: Marinete; FICC, 2011. p. 64.

7 LLOYD, Reginald. Impressões do Brasil no século vinte. Londres: Lloyd's Greater Britain Publishing Company, 1913. Disponível em: http://www.novomilenio.inf.br/santos/h0300g00.htm. Acesso em: 26 jul. 2019.

8 Jornal de Ilhéus, Ilhéus, 26 jan. 1913, ano I, p. 1(grifos nossos). Centro de Documentação e Memória Regional/Universidade Estadual de Santa Cruz (CEDOC/UESC). 
da região, rumando à Itapira (atual município de Ubaitaba) e alcançando 83 quilômetros. De acordo com o relatório apresentado pela secretaria de agricultura da Bahia em 1928, seus lucros bateram a cifra 1.811:844\$830 (hum milhão, oitocentos e onze contos, oitocentos e quarenta e quatro mil e oitocentos e trinta réis), sendo que o cacau respondia sozinho por $50 \%$ dela. ${ }^{9}$ Do ponto de vista econômico, controlar a única ferrovia da maior zona produtora de cacau das Américas também potencializava a rentabilidade dos ingleses. Vale lembrar que os britânicos controlavam parte considerável das áreas produtoras do "fruto do ouro" do mundo, sobretudo em função de seus domínios em Gana e Nigéria, do outro lado do Atlântico. Obter o monopólio do escoamento da produção brasileira - baiana destinada à exportação realçava suas possibilidades de ganho. Ao verificar estas informações, não foi por acaso que a reação de trabalhadores pobres, humildes, porém insubordinados no campo de obras, fosse vista pelas autoridades e chefes como ameaça da ordem e sinais de selvageria.

Se por um lado a Estrada de Ferro era um sinal da força do capitalismo no sul da Bahia, por outro lado, trazia consigo aumento do operariado urbano para llhéus e Itabuna. A partir dos anos 1920, os ferroviários tornaram-se uma categoria profissional numerosa para a realidade regional. Entre administradores e mecânicos, ela contava com uma diversidade social e cultural que contemplava desde o trabalhador qualificado, detentor de ofício especializado como funileiros, eletricistas, carpinteiros, etc., até aqueles de funções manuais como carregadores de lenha. Esses trabalhadores vão se organizar para pedir a aplicação de leis sociais, mas também vão enfrentar as dificuldades das condições de trabalho adversas e até mesmo humilhações, como será abordado em seguida.

9 RELATÓRIO apresentado ao Exmo. Sr. Dr. Vital Henrique Batista Soares pelo engenheiro civil Mario de Souza Dantas, secretário de agricultura, indústria, comércio, viação e obras públicas, 1929. Fundo: Secretaria do Governo, Cx. 2387 / Maço 184, doc. 682. Arquivo Público do Estado da Bahia (APEB). 


\section{Figura 1}

Vista de cima da Estação de Ilhéus.

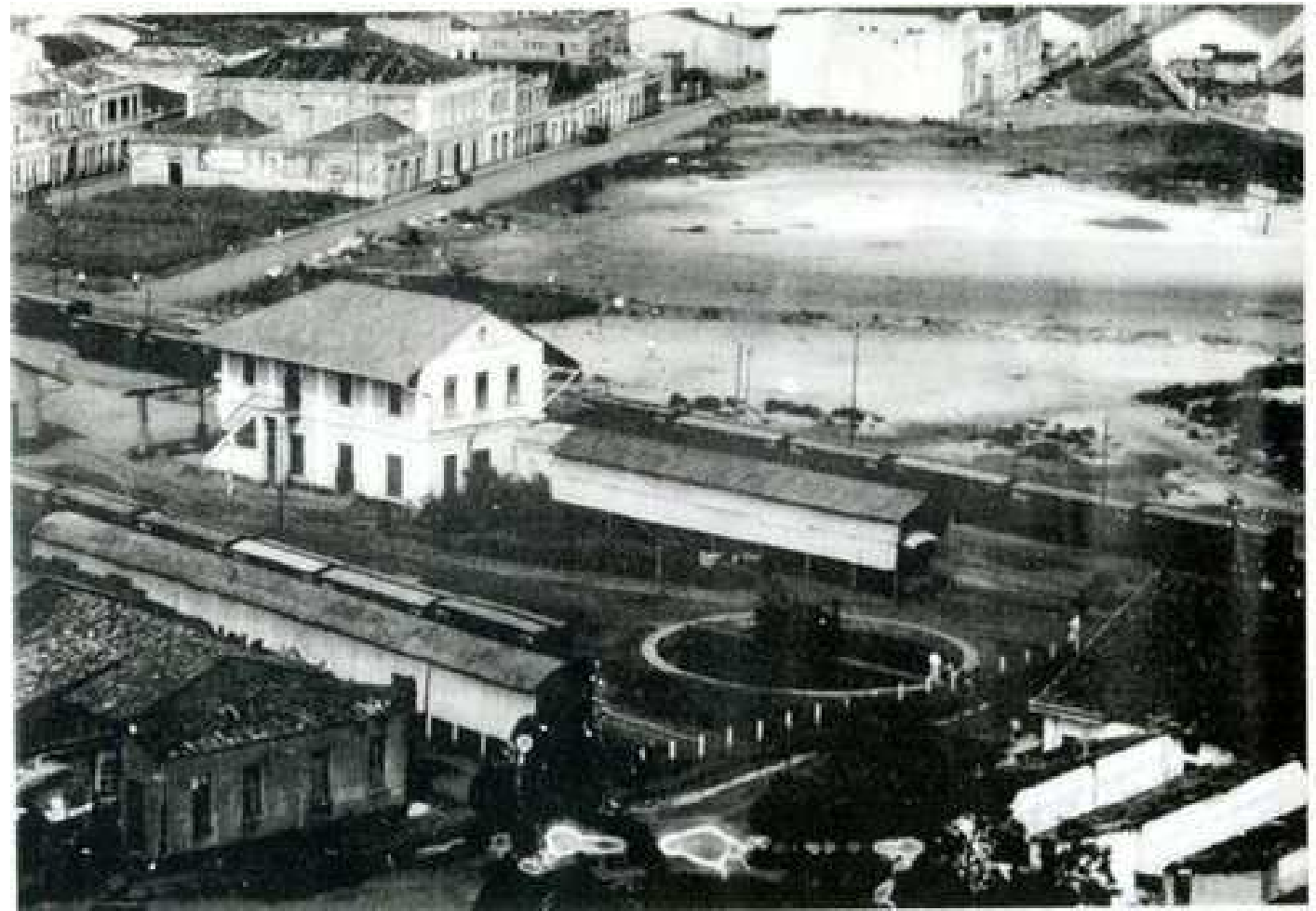

Fonte: POPOFF (1920?)

\section{Os ferroviários e as condições de trabalho na State antes da greve}

Na década de 1920, os ferroviários não tinham uma associação de classe específica de atuação. Eles estavam abrigados na União Protetora dos Artistas e Operários em Ilhéus (UPAOI), fundada em 1922, acompanhados de outras categorias de artesãos e trabalhadores de ofício. No interior destas associações, eles se organizaram em torno do mutualismo, cujo objetivo era assistir seus associados em casos de acidentes de trabalho, doenças ou morte. Mas eles atuavam também em casos de perseguições policiais injustas, fornecendo assistência jurídica. Por último, ofertavam também uma escola noturna para seus membros e seus filhos obterem a instrução primária. Outra importante função da União Protetora foi acompanhar as primeiras leis sociais do trabalho promulgadas ao final da Primeira República. Em abril de 1926, nas proximidades das comemorações do $1^{\circ}$ de maio, os sócios da agremiação operária anunciaram a implementação da jornada diária de 
8 horas do trabalho. O local escolhido para implementar foi a Estrada de Ferro llhéusConquista. ${ }^{10}$

Um ano antes, os ferroviários da União Protetora se envolviam também noutra pauta importante do movimento operário brasileiro. Em 14 de julho de 1925, o ferroviário José Correia de Queiróz escreveu uma carta para o deputado José Wanderley de Araújo Pinho pedindo esclarecimento sobre a Lei Elói Chaves que estabeleceu as regras da previdência para os ferroviários por meio das Caixas de Aposentadorias e Pensões (CAP). O operário queria se certificar de que os funcionários com menos de 10 anos de atividade na companhia de trem teriam direito ao benefício de previdência contido na lei, pois havia notícias, no seio das sociedades operárias ilheenses, de que o governo estaria criando dificuldades para a categoria. ${ }^{11}$ Essas breves informações indicam como os ferroviários eram um segmento que se organizava e que atuava significativamente em llhéus. Por sinal, dois anos após terem criado sua própria Caixa de Aposentadorias e Pensões, os relatórios de prestação de conta informaram que havia 294 funcionários associados, sendo 16 da administração e almoxarifado, 86 do setor de tráfego, 78 da locomoção e 114 na via permanente. $^{12}$

Com quase 300 funcionários associados relatados na Caixa de Aposentadorias e Pensões, é muito provável que a Estrada de Ferro llhéus-Conquista fosse uma das maiores empresas empregadoras de llhéus na década de 1920. Até 1928, ela era considerada a mais bem conservada pelo governo da Bahia. ${ }^{13}$ Apesar das referências positivas, a companhia era alvo frequente de reclamações sobre as condições de suas locomotivas e sobre acidentes de trabalho. Em 18 de junho de 1924, por exemplo, o operário João Macedo foi esmagado por uma das composições após uma manobra na estação de Itabuna. Socorrido pelos companheiros, o trabalhador faleceu no dia 22, no hospital Santa Cruz. De acordo com o jornal O Dia, a "triste e miserável sorte" dos operários da State era consequência do "material que precisa de reforma e não se faz, deixando que os pobres empregados sejam vítimas de carros sem as competentes buchas". ${ }^{14}$

Se cruzarmos as queixas de acidentes com as despesas com assistência médica e intervenções cirúrgicas contidas nos relatórios da CAP, é possível imaginar

10 Correio de Ilhéus, Ilhéus, 24 abr. 1926, ano VI, n. 739, p. 1. APMIJM.

11 CARTA de José Correia de Queiróz ao deputado Wanderley Pinho, Ilhéus, 14/7/1925. f. 1. Fundo Wanderley Pinho, série correspondências. DL1483/004. Instituto Histórico Geográfico Brasileiro (IHGB).

12 Correio de llhéus, Ilhéus, 25 abr. 1929, ano 9, n. 1182, p. 1. APMIJM.

13 RELATÓRIO apresentado ao Exmo. Sr. Governador do Estado Francisco Marques de Góes Calmon, pelo secretário da Agricultura Nelson Spínola Teixeira - Quatriênio 1924-1928. Bahia, 1928, p. 60. APEB.

14 O Dia, Ilhéus, 28 jun. 1924, ano 5, n. 261, p. 2. Instituto Geográfico Histórico da Bahia (IGHB). 
que havia outros incidentes corriqueiros que não chegavam às folhas da imprensa. Em dados extraídos dos relatórios de 1927, a previdência dos ferroviários gastou 18:877\$200 com a saúde de seus membros, sendo que o montante de 6:048\$700 isto é, $32 \%$ dos seus custos - foi gasto com intervenções cirúrgicas e tratamento médico dos contribuintes. Em 1928, as despesas elevaram-se para 21:567\$800, com o valor de 11:967 $\$ 800$ destinados a internações, cuidados médicos e cirurgias. ${ }^{15}$ Aqui podemos imaginar que uma parte considerável desses gastos ocorriam em função de doenças ou de acidentes ocasionados no espaço de trabalho.

Havia reclamações que se referiam também aos maus-tratos dos gerentes da EFIC. O Pequeno Jornal noticiou que a "inglesada" que administrava a empresa perseguia qualquer funcionário brasileiro que se desse conta do trabalho pesado a que estavam submetidos, com "ameaças de demissão e outras penas ... aos nossos patrícios". Para ilustrar as acusações, a notícia narrou um caso ocorrido na State: uma composição de trem de lastro havia partido de madrugada com funcionários para carregar a lenha a ser queimada como combustível no distrito de Urucutuca. O retorno a llhéus ocorreu por volta das 15h, quando os "homens cansados, extenuados pela atividade desenvolvida e pela fome, ... receberam a ordem de descarregar a lenha sem demora e sem refeição". Em função disso, os trabalhadores desaprovaram a ordem e demonstraram sua insatisfação. Para o jornal, foi o que bastou para que "um inglezote recém-chegado impusesse a demissão pela parada do trabalho ... sem apelação e nem agravo". Como se não fosse o bastante, ordenou que o serviço da descarga da lenha fosse realizado pela turma dos recebedores e dos embarcadores da estação. ${ }^{16}$

De acordo com o Pequeno Jornal, por esse motivo, os chefes da ferrovia promoviam perseguição a seus trabalhadores, a fim de evitar que "saibamos das vergonheiras e deslates [sic] que se desenrolam nos atos da administração da companhia inglesa que se organizou para ser o espantalho e o pesadelo da lavoura e do comércio". ${ }^{17}$ Importa dizer que a questão da nacionalidade se tornou assídua nas críticas contra as precárias condições de trabalho e a postura da administração da empresa. A antipatia devotada às atitudes dos ingleses era fomentada por parte da imprensa de llhéus, especialmente quando a companhia tomava medidas que afetavam o comércio e os produtores rurais. No entanto, veremos que, assim como nas paredes dos ferroviários da Estrada de Ferro Bahia-São Francisco em 1909,

\footnotetext{
15 Correio de Ilhéus, Ilhéus, 25 abr. 1929, ano 9, n.1182, p. 2; e 31 mar. 1928, ano 8, n. 1027, p. 2. APMIJM.

16 Pequeno Jornal, Ilhéus, 5 jan. 1927, ano III, n. 195, p. 1. IGHB.

17 Ibidem.
} 
estudadas por Robério Souza, os valores de identidade nacional (patriotismo) combinaram-se com os interesses da classe trabalhadora durante a greve dos ferroviários da llhéus-Conquista em $1927 .{ }^{18}$

A imprensa queixava-se também das locomotivas antigas que faziam o eixo Ilhéus-Itabuna, pois diziam que eram "um verdadeiro perigo para as propriedades e os moradores à margem da linha da State no raio urbano, assim como para os transeuntes que the passem ao alcance dos vômitos das fagulhas". Havia uma das locomotivas apelidada de "mãe da estrada" por ser antiga, não possuir tampa em sua chaminé e soltar uma "chuva de fogos" durante a sua passagem. Criticando os administradores estrangeiros, o Pequeno Jornal dizia que "do alto do seu pombal os ingleses assistem impassíveis, carrancudos, a devastação produzida pela esbodegada máquina". ${ }^{19} \mathrm{Em}$ 1927, os maus-tratos dos gerentes ingleses, as condições precárias da ferrovia e a reivindicação de reajuste salarial tornaram-se justificativas para a deflagração da greve. Vejamos a seguir.

\section{A greve ferroviária desembarca no sul da Bahia}

Em maio de 1927, os empregados das ferrovias baianas levantaram-se em diversas greves que atingiram a capital e o interior. As primeiras paralisações ocorreram no sistema da Companhia Este Brasileiro em suas duas principais estradas: Central da Bahia e Bahia-São Francisco. De acordo com José Raimundo Fontes, o descontentamento com as condições de trabalho e com os baixos salários era demonstrado há algum tempo pelos funcionários da companhia, o que levou a administração a elaborar um quadro de salários com valores mínimos e máximos para as diárias e os ordenados, a jornada diária de 8 horas e o pagamento de horas extras. Apesar da aprovação do Ministério da Viação, os diretores da ferrovia continuaram pagando os salários antigos, motivando os funcionários a cruzarem os braços em Salvador, a partir de 9 de maio. ${ }^{20}$

Entre 10 e 22 de maio, o movimento grevista ganhou força na capital e no interior. Das cidades de Alagoinhas e Bomfim, além dos distritos de Aramari e Periperi, os funcionários telegrafaram aos colegas da capital reafirmando seu comprometimento com a parede até que se alcançasse os seguintes pleitos: aumentos relativos dos ordenados até $30 \%$; e depósito de oitocentos réis na Caixa

\footnotetext{
SOUZA, op. cit., p. 150.

9 Pequeno Jornal, Ilhéus, 5 jan. 1927, ano 3, n. 195, p. 1. IGHB.

20 FONTES, José Raimundo. Manifestações operárias na Bahia: o movimento grevista - 1888-1930. 1982. Dissertação (Mestrado em História) - Universidade Federal da Bahia, Salvador, 1982. p. 200.
} 
de Aposentadoria dos Operários. Posteriormente, foi anexada à pauta a saída do superintendente Edmon Oliveira da administração da empresa. Outro fator em favor dos grevistas foi a troca constante de informações com os ferroviários de Aracaju. Isso nos dá a dimensão da capacidade de se conectarem e de se organizarem com colegas de diferentes regiões da Bahia, e até mesmo de Sergipe, apesar das distâncias e dos obstáculos materiais.

As negociações entre a comissão de greve e os administradores da companhia não lograram êxito, o que gerou uma pressão cada vez maior da imprensa e de entidades patronais da capital, do recôncavo e do sertão baiano para que o governo intervisse por uma solução dos conflitos. ${ }^{21} \mathrm{Em} 17$ de maio, os empregados de São Félix e de Cachoeira também aderiram ao movimento. Dias antes, as primeiras notícias chegaram também ao sul da Bahia pela imprensa, tratando dos impactos da paralisação dos transportes no comércio de gêneros de primeira necessidade e da "atitude calma, mas irredutível" dos grevistas. ${ }^{22}$

Informações detalhadas da greve chegaram com os ferroviários da Este Brasileiro ao porto de Ilhéus em 20 de maio de 1927. Em busca de solidariedade, os paredistas da capital reuniram-se com os funcionários ilheenses e distribuíram boletins explicativos dos motivos da paralisação realizada em Salvador e em Aracajú, conforme transcrevemos abaixo:

\section{ALERTAS, CAMARADAS!}

Apelo dos ferroviários da Este Brasileiro aos seus colegas da "Ilhéus à Conquista".

Irmãos, as empresas de estradas de ferro, no momento atual, exploram-nos impiedosamente. Dão-nos um salário ridículo em troca de um trabalho árduo. Aos nossos rogos de aumento não atendem enganando-nos com promessas falazes, irrealizáveis. Assim, pois, decretamos greve pacífica para a reabilitação de nossos direitos. Dela não cederemos um passo sem a vitória.

Felizmente contamos com o apoio dos nossos colegas de todas as linhas da "Este Brasileiro", o que reforça as nossas convicções e nos garante o triunfo.

Queremos também, o apelo de todos vós, da "Ilhéus à Conquista", que sois, como nós, explorados sem dó nem piedade.

Declarai-vos em greve pacífica, unindo-vos, todos, sem discrepância, e sereis vitoriosos.

ABAIXO A TIRANIA!

VIVA O OPERARIADO!23

Ibidem, p. 201-204.

22 Correio de Ilhéus, Ilhéus, 14 maio 1927, ano 7I, n. 891, p. 1. APMIJM. Outras notícias podem ser encontradas em A Época, Ilhéus, 14 maio 1927, ano X, n. 101, p. 1. CEDOC/UESC.

23 Boletim encontrado em IGHB. Pequeno Jornal, Ilhéus, 23 maio. 1927, ano III, n. 239, p. 1. 
Em reunião na União Protetora em Ilhéus, os ferroviários acataram a convocação dos colegas da capital. Ficou combinado que a paralisação seria deflagrada na madrugada de 23 de maio, uma segunda-feira, quando um trem de carga deveria partir em viagem. Do lado oposto, os diretores da Estrada de Ferro, cientes das primeiras movimentações, encontraram-se na sede da empresa para debater a possibilidade de greve, tendo percorrido os departamentos, as oficinas e as locomotivas para vistoriar o ambiente. ${ }^{24}$

Às 7h, a estação de llhéus já estava em polvorosa com os empregados da ferrovia de braços cruzados, além de passageiros e curiosos que também se aglomeravam no local. Notificado do ocorrido, o superintendente Francis Hull procurou os grevistas e pediu que dessem partida no trem das 8h. Houve recusa, embora dois engenheiros ingleses tenham feito fogo e dado sinal de partida da locomotiva. Logo em seguida, ocorreu uma conferência entre uma comissão de ferroviários de todas as sessões (à exceção dos funcionários do escritório central), acompanhada do advogado Edgar Lyra, de José F. de Oliveira (redator do Pequeno Jornal), e dos diretores da companhia Brown, Hull e Bento Berilo, mais o engenheiro Jayme Guimarães, para discutir a paralisação. ${ }^{25}$

\section{Figura 2}

Chegada do trem a estação de Ilhéus, 1928.

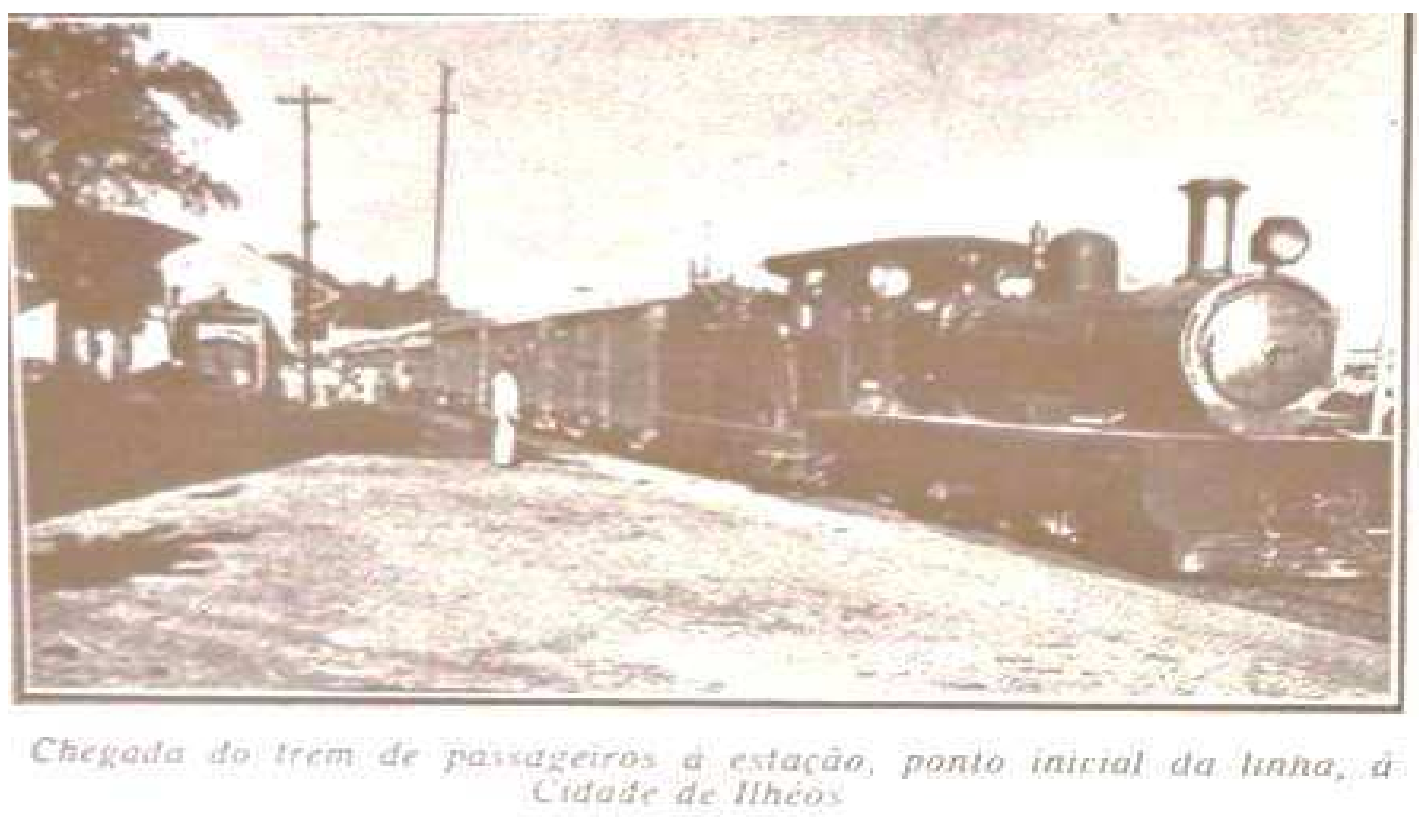

Fonte: FOLGUEIRA, Manuel Rodrigues, Álbum artístico, comercial e industrial da Bahia, 1930.

24 Ibidem.

25 Boletim encontrado em IGHB. Pequeno Jornal, Ilhéus, 23 maio. 1927, ano III, n. 239, p. 1. Outras informações também foram registradas pelo APMIJM. Correio de Ilhéus, Ilhéus, 24 maio 1927, ano 7 , n. 895 , p. 1 . 
Os prepostos dos ferroviários ressaltaram a atitude pacífica do movimento grevista e a coesão da categoria. O chefe da empresa Bento Berilo disse que a declaração de greve vinha a ex abrupto e, por isso, pedia tempo para resolver a questão do aumento dos ordenados, e que os funcionários voltassem ao trabalho. Os paredistas não cederam e dirigiram a pauta de reivindicações por escrito à empresa. Avisaram também que mantinham a paralisação até que a resposta dos patrões fosse encaminhada. No documento entregue aos chefes, os funcionários da State disseram:

\begin{abstract}
Numa atitude toda pacífica e abandonando desde hoje pela manhã os nossos serviços, vimos pela presente pleitear junto a essa superintendência o aumento de trinta por cento (30\%) em nossos vencimentos, bem como que se converta em ordenado fixo a gratificação que estamos recebendo, vai já por algum tempo.

É força que pondere essa superintendência sobre o que ora se acha exposto, atendendo-se ainda mais à vida sobremaneira difícil neste município, onde com o ordenado presente não podemos por modo nenhum equilibrar a receita com a despesa, isto é, manutenção de nossas famílias.
\end{abstract}

Assim, nesta atitude permaneçamos todos, com o propósito firme de não comparecermos ao serviço, até que se resolva tão momentoso assunto.

Solucionando que seja por essa superintendência o apelo que ora se faz, firmamos o solene compromisso de voltarmos todos ao trabalho, sem nenhuma alteração, dessa data por diante.

Vai já para mais de um ano igual apelo já se fez a essa companhia, conforme se vê, até o momento, justo apelo este que não foi por ela tomado na devida consideração, motivando deste jeito a presente atitude.

Isto posto, aguardamos, confiantes em breve tempo a solução de tão justo pedido. ${ }^{26}$

As reivindicações dos ferroviários de llhéus eram similares às dos colegas de outras regiões da Bahia. No entanto, convém ressaltar que a greve de 1927 não foi apenas um reflexo das mobilizações ocorridas na capital, pois, como se nota na citação acima, havia negociações com os chefes da State há pelo menos um ano para tratar da melhoria dos salários. Aliás, vale dizer que as remunerações dos empregados brasileiros eram bem inferiores aos ordenados dos ingleses. A imprensa chamava o quadro de salários de "Tabela da Fome", pois havia trabalhadores cujas remunerações não alcançavam $100 \$ 000$ mensais, enquanto o Superintendente Hull recebia 10 contos de réis (ver tabela de salário no anexo). ${ }^{27}$

26 Ibidem, p. 1-2.

27 Correio de Ilhéus, Ilhéus, 26 maio 1927, ano 7I, n. 896, p. 2. APMIJM. 
Os grevistas deram também destaque ao perfil pacífico da paralisação, muito embora, desde o princípio, tenham sido fiscalizados pela polícia. No interior do município ilheense e na vizinha cidade de Itabuna, as notícias chegaram com agilidade. Às 14h, uma locomotiva guiada pelo maquinista Raul Souza trouxe a llhéus mais de 120 funcionários do interior para engrossar as fileiras da greve. Naquela mesma tarde, os grevistas se encaminharam para o paço municipal, onde procuraram o intendente Mário Pessoa para prestar contas do movimento e solicitar sua intermediação com os patrões. ${ }^{28}$

Tabela 5 - Salários da estrada de ferro Ilhéus-Conquista, 1927.

\begin{tabular}{|c|c|}
\hline \multicolumn{2}{|c|}{$\begin{array}{l}\text { QUADRO DE SALÁRIOS DA ESTRADA DE FERRO ILHÉUS-CONQUISTA } \\
\text { ADMINISTRAÇÃO }\end{array}$} \\
\hline $\begin{array}{ll} & \text { AD } \\
\text { Cargo } & \end{array}$ & \\
\hline Superintendente (com casa e criados) & 9:500\$000 (208 libras) \\
\hline Advogados & $1: 200 \$ 000$ \\
\hline Secretário & $730 \$ 000$ \\
\hline Contador (com aluguel de casa) & $1: 700 \$ 000$ \\
\hline Assistente & $800 \$ 000$ \\
\hline Almoxarife & $530 \$ 000$ \\
\hline Escriturários & $300 \$ 000$ \\
\hline Vigia & $110 \$ 000$ \\
\hline Servente & $145 \$ 000$ \\
\hline \multicolumn{2}{|l|}{ VIA PERMANENTE } \\
\hline Cargo & Remuneração \\
\hline Engenheiros (com casa) & $1: 600 \$ 000$ \\
\hline Assistente & $700 \$ 000$ \\
\hline Mestre de linha & $355 \$ 000$ \\
\hline Escriturário & $315 \$ 000$ \\
\hline Eletricista & $330 \$ 000$ \\
\hline Apontador & $280 \$ 000$ \\
\hline Feitores & De $130 \$ 000$ a $180 \$ 000$ \\
\hline Trolistas & $90 \$ 000$ \\
\hline Operários & De $8 \$ 000$ a $10 \$ 000$ diária \\
\hline Bombeiros & $3 \$ 500$ diária \\
\hline Rodantes & $3 \$ 300$ diária \\
\hline Encarregado de cerca & $3 \$ 000$ a $5 \$ 000$ diária \\
\hline \multicolumn{2}{|l|}{ TRAFEGO } \\
\hline Cargo & Remuneração \\
\hline Chefe (inclusive aluguel de casa) & $1: 200 \$ 000$ \\
\hline Escriturário & $280 \$ 000$ \\
\hline Agentes de estações & De $180 \$ 000$ a $450 \$ 000$ \\
\hline Subagente & $100 \$ 000$ a $320 \$ 000$ \\
\hline Fiel & $300 \$ 000$ \\
\hline Fiscal de trens & $300 \$ 000$ \\
\hline Condutores & $130 \$ 000$ a $220 \$ 000$ \\
\hline Conferentes & $150 \$ 000$ a $300 \$ 000$ \\
\hline
\end{tabular}

28 A Época, llhéus, 29 maio 1927, Ano 10, n. 103, p. 2. CEDOC/UESC. 


\begin{tabular}{|lc|}
\hline Bilheteiro & $200 \$ 000$ \\
\hline Despachante & $180 \$ 000$ a $300 \$ 000$ \\
\hline Faturista & $220 \$ 000$ \\
\hline Encarregado de bagagem & $250 \$ 000$ \\
\hline Balanceiro & $200 \$ 000$ \\
\hline Manobreiro & $150 \$ 000$ \\
\hline Estafeta & $80 \$ 000$ \\
\hline Guarda-chave & $3 \$ 300$ a $3 \$ 800$ diária \\
\hline Guarda e servente & $3 \$ 300$ a $3 \$ 800$ diária \\
\hline Guarda-freios & $3 \$ 300$ a $4 \$ 200$ diária \\
\hline & \\
\hline LOCOMOÇÃo & Remuneração \\
\hline Cargo & $1: 800 \$ 000$ \\
\hline Chefe de locomoção (com aluguel de & $450 \$ 000$ \\
\hline casa) & $300 \$ 000$ \\
\hline Mestre das oficinas & $300 \$ 000$ \\
\hline Escriturário & $5 \$ 000$ a $12 \$ 000$ diária \\
\hline Mestre carpinteiro & $1 \$ 000$ a $2 \$ 5000$ diária \\
\hline Ajustadores & $6 \$ 000$ a $10 \$ 000$ diária \\
\hline Aprendizes & $3 \$ 000$ a $6 \$ 000$ diária \\
\hline Torneiros & $6 \$ 000$ a $10 \$ 000$ diária \\
\hline Ajudadores torneiros & $5 \$ 000$ diária \\
\hline Ferreiros & $4 \$ 500$ diária \\
\hline Malhador & $6 \$ 500$ diária \\
\hline Modelador & $5 \$ 000$ a $8 \$ 000$ diária \\
\hline Latoeiro & $4 \$ 500$ a $8 \$ 000$ diária \\
\hline Reparadores & $5 \$ 000$ a $8 \$ 000$ diária \\
\hline Pintores & $3 \$ 500$ a $5 \$ 000$ diária \\
\hline Carpinteiros & $140 \$ 000$ a $325 \$ 000$ \\
\hline Operários & $75 \$ 000$ a $150 \$ 000$ \\
\hline Maquinista & $70 \$ 000$ a $110 \$ 000$ \\
\hline Foguista & $140 \$ 000$ \\
\hline Limpadores & $130 \$ 000$ \\
\hline Vigia & \\
\hline Apontador & \\
\hline Fonte: Corre de & \\
\hline
\end{tabular}

O primeiro dia da paralisação foi encerrado na sede da União Protetora, às 20h, quando foi realizada uma assembleia com o objetivo de formar uma comissão de greve dos ferroviários. ${ }^{29}$ Houve também a formação do bando precatório, grupo responsável por angariar fundos. Ao final, houve uma moção de solidariedade de todas as sociedades operárias em apoio à atitude dos paredistas. ${ }^{30}$ Nesse sentido, importa enfatizar o papel cumprido no campo das reivindicações pela cultura associativa mutualista tecida no Sul da Bahia. Por diversos momentos, as sociedades de auxílio mútuo das diversas categorias profissionais prestaram apoio com a

29 A representação foi composta por Theodoro Santos, Ubaldino Oliveira, Deolindo Neves, Durval Dias, Cantídio de Oliveira, José Cerqueira Lima, Archelau Oliveira, Francisco Ferreira, José Vitorino de Souza e Lisandro Melchíades.

30 Pequeno Jornal, Ilhéus, 25 maio 1927, ano 3, n. 240, p. 1. IGHB. 
arrecadação de dinheiro, a abertura das sedes para reuniões, fazendo-se inclusive presentes nas atividades de greve. Por sinal, parte dos grevistas era sócia da União Protetora, o que justificava o fato das assembleias serem realizadas naquela agremiação durante as paralisações.

A greve dos ferroviários de llhéus contou com o apoio da imprensa de llhéus e de Itabuna. Em Ilhéus, tanto o Pequeno Jornal como o Correio de Ilhéus descreveram a paralisação como o instrumento de "defesa dos sagrados interesses" e das "justas reivindicações", respectivamente. O sentido de expressões como "sagrados interesses" e "justas reivindicações" revela o sentido paternalista da imprensa das classes dominantes em conceder seu apoio às lutas dos de baixo enquanto estes se mantivessem na ordem e sem quebras de hierarquias com as autoridades municipais. Além disso, esses jornais contavam com jornalistas e intelectuais que tinham vínculos com o movimento operário de Ilhéus, como era o caso do jornalista Nelson Schaun e de José F. de Oliveira.

José F. de Oliveira era proprietário do Pequeno Jornal, periódico que circulava semanalmente em llhéus, mas que não estava entre os mais importantes da cidade. Havia matérias frequentes que abordavam as condições de trabalho e as causas dos operários do sul da Bahia. Ao mesmo tempo, as reportagens eram críticas para alguns patrões, como donos de casas comerciais sírio-libanesas e chefes ingleses da companhia, vistos por Oliveira como os responsáveis por aquela situação de greve. Ele falava que "ao passo que assim vinha o trabalho do natural [brasileiro] desvalorizado, restringido seu salário a proporções irrisórias, o pessoal inglês nadava em libras esterlinas, com ordenados nababescos para encargos relativamente pequenos" e justificava que a "chocante desigualdade cavou, dia a dia, o desfecho que hoje assistimos, da greve geral, por parte dos ferroviários nacionais". ${ }^{31}$

Já Schaun era um típico interlocutor entre as classes operárias e os políticos das oligarquias ilheenses, especialmente da família Pessoa que dominava o poder municipal desde $1912 .^{32}$ Ele participava ativamente da cultura associativa dos trabalhadores na década de 1920, quando se tornou inclusive presidente da Associação dos Empregados em Ilhéus entre 1927-1928. Sua atuação nos círculos operários esteve combinada com sua participação no Partido Republicano da Bahia,

31 Pequeno Jornal, Ilhéus, 23 maio 1927, ano III, n. 239, p. 1. IGHB.

32 Para saber mais da biografia de Nelson Schaun, Cf. SCHAUN, Maria (org.). Nelson Schaun, merece um livro... Ilhéus: Editus, 2001. Para tratar da política e das oligarquias do sul da Bahia, Cf. RIBEIRO, André Luiz Rosa. Família, Poder e Mito: o município de São Jorge dos Ilhéus (18801930). Ilhéus, BA: Editus, 2001. 
em que exerceu cargos de indicação no conselho municipal entre 1928-1930. ${ }^{33} \mathrm{~A}$ respeito dos protestos e paralisações dos ferroviários, ele escreveu que na Inglaterra havia várias greves operárias e que "não devia causar surpresa, portanto, aos ingleses que dirigem e exploram a Estrada de Ferro llhéus-Conquista, a atitude dos nossos patrícios, defendendo uma causa justa e nobre, advogando pelos interesses da família, contra a ganância de seus patrões". ${ }^{34}$ Sem dúvida, o patriotismo brasileiro contra os ingleses da EFIC era o amálgama que unia as críticas das classes dominantes à greve dos ferroviários.

Os jornais da capital estamparam as notícias da greve em llhéus no dia 24 de maio de 1927. O Diário da Bahia, por exemplo, destacava que a "Estrada IlhéusConquista, que até agora só vai até Itabuna, é inglesa e dá uma renda fabulosa" e que "com a pequena despesa que tem, fica-lhe um saldo vultoso", "enquanto os empregados brasileiros têm salários ridículos". 35 Para Fontes, a entrada dos trabalhadores da State na parede "em muito reforçou as posições dos grevistas da Este Brasileiro". ${ }^{36}$ Nestas condições, o segundo dia de braços cruzados dos ferroviários de llhéus contou com uma programação intensa.

\section{A greve se fortalece}

No segundo dia, 24 de maio, as atividades começaram com uma reunião entre a comissão grevista e a diretoria da Associação Comercial. Desde o início, a entidade patronal intermediou a negociação com a administração da ferrovia, preocupada principalmente em normalizar o tráfego que escoava os produtos agrícolas e comerciais, e diminuir os prejuízos financeiros. Após conversa inicial, a comissão de paredistas, o advogado Edgar Lyra e os diretores da ACIOS dirigiram-se de automóvel para uma conferência com os trabalhadores. É provável que, nesse encontro preliminar, a comissão tenha negociado uma contraproposta para o fim da greve a ser discutida com a base. Depois desta assembleia, a nova proposta feita pelos ferroviários ficava estabelecida nos seguintes pontos:

1) Conservação incondicional de todos os funcionários e operários grevistas e o cancelamento da suspensão por tempo indeterminado imposta ao maquinista Raul Souza;

33 CARVALHO, Philipe Murillo S. de. Trabalhadores, associativismo e política no sul da Bahia (IIhéus e Itabuna, 1918-1934). 2015. Tese (Doutorado em História) - Universidade Federal da Bahia, Salvador, 2015.

34 Correio de Ilhéus, Ilhéus, 24 maio 1927, ano 8, n. 895, p. 1. APMIJM.

35 Diário da Bahia, Salvador, 24 maio 1927, ano 72, n. 116, p. 1. Biblioteca Pública do Estado da Bahia (BPEB).

36 FONTES, op. cit., p. 212. 
2) Aumento de trinta por cento (30\%) até o ordenado de $300 \$$; de $20 \%$ para mais de $300 \$$ até $500 \$$, sendo que ficarão contemplados com o aumento de $30 \%$ todos os diaristas;

3) O registro do quadro de funcionários da Companhia, nas suas respectivas categorias;

4) Chegar ao conhecimento dos grevistas uma comunicação oficial, dirigida pela superintendência, garantindo-lhes clara e precisamente o que ora se pretende;

5) No aumento será incorporada a gratificação. ${ }^{37}$

Com o objetivo de convencer os administradores da State, os ferroviários aceitaram flexibilizar o aumento dos ordenados de acordo com a faixa salarial de cada funcionário. Apesar disso, não houve conciliação e a greve permaneceu. Outra demonstração de antipatia dos chefes da companhia foi a suspensão do maquinista Raul Souza, que havia trazido funcionários do interior do município para a cidade no dia anterior. Para completar, o superintendente Francis Hull deu queixa à polícia do furto de peças das oficinas em que estavam as locomotivas. Provavelmente os ferroviários haviam retirado componentes importantes do maquinário a fim de evitar que os funcionários leais aos chefes pusessem as locomotivas para funcionar e comprometessem a força da paralisação. Segundo o tenente Crispim, os trabalhadores devolveram as peças ao engenheiro fiscal Jayme Guimarães após as abordagens policiais. ${ }^{38}$ De qualquer forma, à medida que os administradores da companhia endureciam as negociações, os grevistas buscavam outros meios para alcançar seus objetivos.

Diante do acentuado clima de tensão e pouca margem de negociação, os grevistas enviaram telegramas para os deputados João Mangabeira, José Wanderley de Araújo Pinho, Vital Soares, Ramiro Berbert de Castro e Salomão Dantas. Na comunicação, diziam que depois de reiterados pedidos de aumento salarial, declararam-se em greve pacífica, aguardando "confiantes providências da bancada baiana". De algum modo, os grevistas fizeram uso de certo poder de pressão sobre os parlamentares que buscavam o apoio operário em época de eleições. Escreveram também para o Conselho Nacional do Trabalho (órgão criado apenas em $1923^{39} \mathrm{com}$ o objetivo de fiscalizar e mediar as relações entre patrões e empregados) para apelar aos "altos poderes constituídos" para a solução de seus problemas, procedimento

37 Pequeno Jornal, Ilhéus, 25 maio 1927, ano 3, n. 240, p. 1. IGHB.

38 Correio de Ilhéus, Ilhéus, 26 maio 1927, ano 7, n. 896, p. 1. APMIJM.

39 VISCARDI, Claudia M. R. Trabalho, previdência e associativismo: as leis sociais na Primeira República. In: LOBO, Valéria Marques. Trabalho, proteção e direitos: o Brasil além da era Vargas. Juiz de Fora, MG: Editora da UFJF, 2010. 
que indica o uso pelos trabalhadores dos órgãos de regulamentação do trabalho então recém-implantados na República. ${ }^{40}$

\section{Figura 3}

Estação de Rio do Braço, de onde Raul Souza partiu com o trem carregado de grevistas para llhéus. 1928.

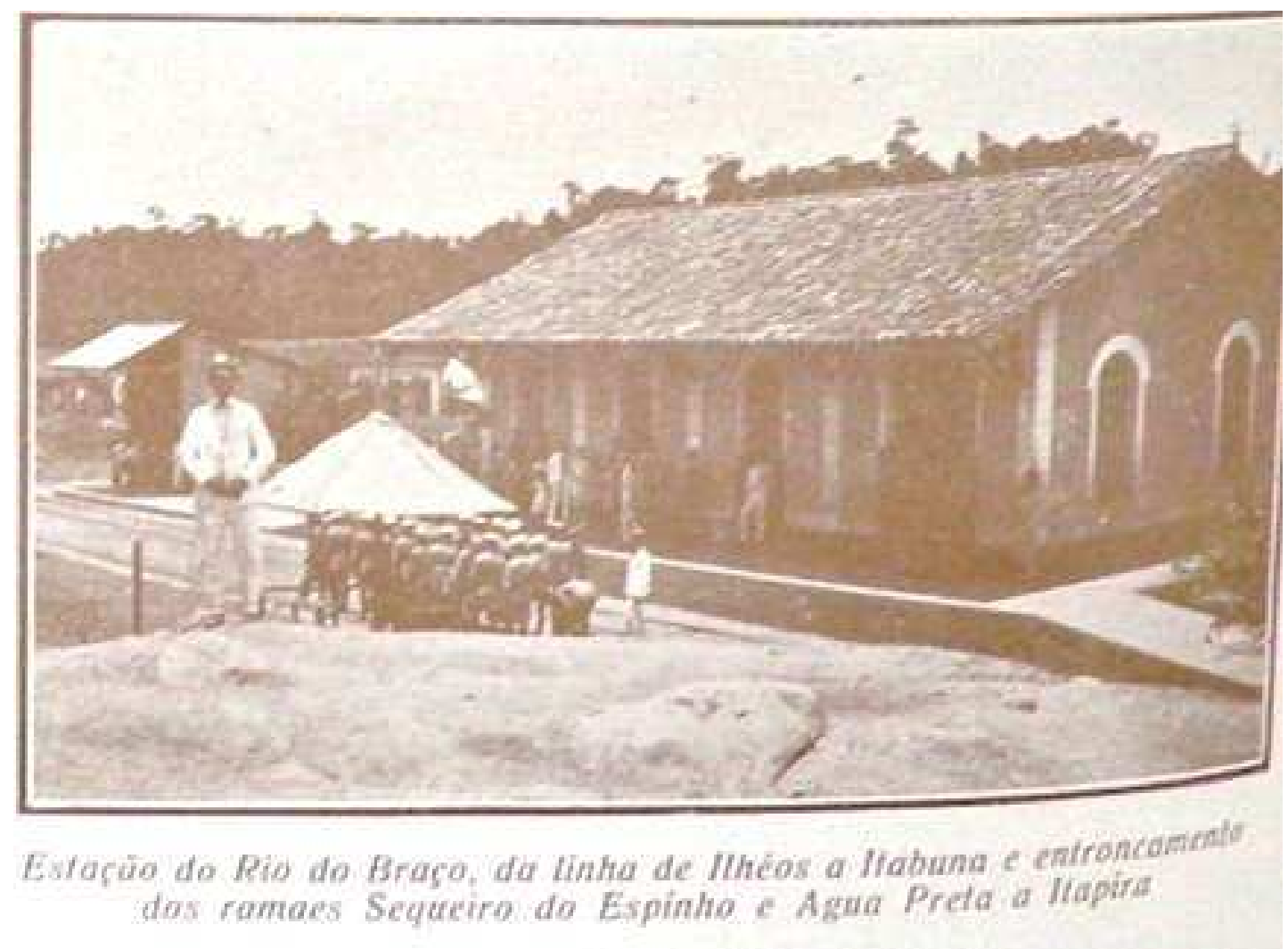

Fonte: FOLGUEIRA, Manuel Rodrigues, Álbum artístico, comercial e industrial da Bahia. [S. I: s. n], 1930.

Enquanto as negociações não avançavam em Ilhéus, na vizinha Itabuna, os ecos da greve ressoavam. No dia 24 , o comércio fechou as portas em solidariedade ao movimento paredista, o que não deve ter sido tão difícil assim, pois a paralisação do tráfego ferroviário praticamente isolou a comunicação por transportes coletivos da cidade. A única estrada rodoviária que ligava os dois maiores municípios estava em péssimas condições e não havia tantos "auto-ônibus e caminhões da "Sul Baiana" capazes de dar "vazão ao aumento do número de passageiros". Em paralelo, circulou a notícia de que os diretores da Sociedade Montepio dos Artistas de Itabuna se organizavam para ir até Ilhéus, auxiliar na "resistência à ganância dos ingleses". ${ }^{41}$

40 Pequeno Jornal, Ilhéus, 25 maio 1927, ano 3, n. 240, p. 2. IGHB.

41 Pequeno Jornal, Ilhéus, 25 maio 1927, ano 3, n. 240, p. 2. IGHB. 
Era outra demonstração do envolvimento do mutualismo operário do sul da Bahia com as greves ferroviárias.

Ao entrar no terceiro dia de paralisação, 25, a causa dos ferroviários tinha ganhado a simpatia popular e mobilizado indivíduos das mais diversas categorias. Prova disso é que uma caminhada em prol do movimento contou com a participação ativa da Associação dos Empregados no Comércio de Ilhéus, da Sociedade União Operária dos Estivadores em Ilhéus e da União Protetora; das agremiações recreativas Grêmio Olavo Bilac, Satélite Sport Clube, Vitória Sport Club, Flamengo F. Clube, S. Salvador Futebol Club; e da filarmônica Euterpe 3 de Maio. De pavilhões erguidos, as sociedades conduziam faixas com os seguintes dizeres: "Chegou a hora das reivindicações", "Protegei o Operariado" e "Guerra à Prepotência". É provável que outras expressões mais fortes tenham sido usadas nas faixas. Isso motivou as críticas do Correio de Ilhéus, ao dizer que "podiam ter dispensado os cartazes com linguagem irreverente e violenta contra seus 'opressores"” e que não condiziam "com a linha de cordura e serenidade com que se vem impondo à pública simpatia os paredistas, desde o primeiro dia de greve". Na repreensão em si, talvez estivesse contido o receio de que o movimento se radicalizasse e fugisse ao controle das autoridades. ${ }^{42} \mathrm{O}$ cortejo que se seguiu até o porto da cidade foi um sucesso para o movimento paredista. Além de ter mobilizado um contingente expressivo, incluindo outras categorias de trabalhadores, os grevistas conseguiram arrecadar 2:460 $\$ 000$ (dois contos e quatrocentos e sessenta mil réis) em doações.

Enquanto os ferroviários caminhavam pelas ruas da cidade, o intendente Mario Pessoa e o governador Góes Calmon trocavam telegramas sobre a importância de pôr fim à paralisação, sobretudo em função das "graves consequências que o movimento grevista acarretará na vida econômica do estado e nessa região". Fica claro que o objetivo principal era evitar os prejuízos financeiros dos patrões e dos poderes públicos. Por isso, no dia 26 , o chefe da cidade tentou novo acordo com a State. Ele convocou uma reunião com seus representantes, Mr. Francis Hull, Mr. Brown e cel. Bento Berillo, os diretores da Associação Comercial, o presidente do Conselho Municipal, Antonio Pessoa, e o advogado Edgar Lyra. Enquanto conversavam no Palácio da Intendência, os grevistas se aglomeraram na Praça Seabra, à frente do Paço Municipal. Após duas horas e meia, não houve avanços na negociação, e uma mistura de frustração e indignação tomou conta dos trabalhadores. ${ }^{43}$

42 Ibidem, p. 1-2. Correio de Ilhéus, Ilhéus, 26 maio 1927, ano 7, n. 896, p. 1-2. APMIJM.

43 Pequeno Jornal, Ilhéus, 27 maio 1927, ano 3, n. 241, p. 1. IGHB. 
A imprensa criticou novamente os administradores da Estrada de Ferro. $\mathrm{O}$ Pequeno Jornal escreveu que o "único culpado pelo estado atual das coisas" era a "irredutibilidade dos diretores da State". Informou que, quando as notícias sobre o fracasso das conversações ecoaram na praça, "as vociferações explodiram incontidas contra os famigerados espoliadores de nossas energias". A partir daí, organizou-se uma série de atividades que contaram com o apoio de autoridades e associações operárias. A primeira delas ocorreu ali mesmo na Intendência, onde Nelson Schaun da sacada principal "fez vibrar o povo em belo improviso de repulsa às atitudes britânicas". ${ }^{44} \mathrm{O}$ intendente Mário Pessoa teria dirigido "palavras causticantes" e "censurado" o procedimento intransigente dos diretores da companhia. Convém frisar que posicionar-se ao lado dos grevistas era a forma pela qual Pessoa assumia as bandeiras dos trabalhadores e encenava sua política de coexistência com os "de baixo", sobretudo porque a greve não pôs a ordem pública em xeque.

Por volta das $16 \mathrm{~h}$ do dia 26 , outro comício, na Praça Cairú, próxima à estação ferroviária, contou novamente com Nelson Schaun, que, acompanhado dos ferroviários, fez vários discursos e distribuiu boletins falando das injustiças cometidas. Em seguida, novo encontro foi marcado para as 20h, na sede da União Protetora. Durante o intervalo, os grevistas procuraram o delegado Crispim para denunciar o fato de que alguns engenheiros estavam fazendo manobras imprudentes e danificando o maquinário com a intenção de culpar os ferroviários posteriormente. Em certificado publicado no Pequeno Jornal, a autoridade policial reconhecia ter encontrado o chefe da locomoção escondido no carro 13, garantindo realizar rondas periódicas para evitar outros problemas. Desta vez, foram os trabalhadores que correram para a polícia para garantir-Ihes o direito da greve pacífica em meio ao acirramento das tensões. ${ }^{45}$

Já pela noite do dia 26, realizou-se a assembleia na União Protetora. A comissão paredista anunciou que havia obtido doações dos estudantes do Colégio Ginásio Castro Alves no valor de 50\$000, de moradores do distrito de Rio do Braço na quantia de $190 \$ 000$ e do major Jerônimo Ferreira no montante $400 \$ 000$. Igualmente, a loja maçônica Regeneração Sul Baiana promoveu um espetáculo no Cine Pery em benefício dos paredistas, o que era um "vibrante atestado da simpatia da causa dos ferroviários". ${ }^{46}$ Com isso, é possível dizer que as redes de solidariedades se ampliaram, pois a população em geral se afeiçoou às "justas

44 Ibidem, p. 1-2.

45 Ibidem.

46 Pequeno Jornal, Ilhéus, 27 maio 1927, ano 3, n. 241, p. 1. IGHB 
reivindicações" do operariado da Estrada de Ferro. Finalmente ficou decidido na assembleia que a comissão grevista, acompanhada dos jornalistas José F. Oliveira e Nelson Schaun, dos representantes da União Protetora, Camillo Lellis, da União dos Carregadores de Ilhéus, Ozeas Medeiros, da União dos Estivadores, Honório Antônio Martins (apenas para citar as agremiações operárias), iriam a Itabuna para entrar em contato com sociedades operárias e realizar comícios e passeatas pelas ruas das cidades no dia seguinte.

No dia 27 de maio, os grevistas rumaram para Itabuna em montarias. Depois de quase um dia de viagem, os visitantes foram recebidos pelos diretores da SMPAI e acertaram a programação. Já a 28 do mês, ocorreu uma assembleia com os grevistas, os representantes de associações operárias, de sociedades recreativas e beneficentes de llhéus e de Itabuna, cuja finalidade era buscar o apoio da população itabunense à parede dos ferroviários. Formou-se um bando precatório com três comissões a fim de arrecadar fundos financeiros para o movimento. ${ }^{47}$

Havia muitas lideranças oligárquicas presentes na SMPAI, o que era um sinal de que eles desejavam acompanhar os desdobramentos do protesto, mas também de exercerem seu papel de autoridade diante dos operários em greve. Da parte do PRD (ex-seabristas), estavam no recinto Gileno Amado, Martinho Conceição (também presidente da Associação Comercial de Itabuna), Antônio Cordeiro de Miranda e Soriano Neto. Pelo lado do situacionista PRB, encontravam-se o advogado Lafaiete de Borborema, o delegado Deocleciano Portela (que representava o deputado estadual Salomão Dantas), além de Flaviano Moreira, Elpídio Soares e Edgar de Barros. Por sinal, as comissões foram compostas por autoridades e intelectuais dos partidos locais, que saíram pela cidade durante o dia de 28 e arrecadaram 1:780\$000 (hum conto e setecentos e oitenta mil réis). ${ }^{48} \mathrm{~A}$ presença dos chefes políticos indica o relevo que a causa dos grevistas alcançou perante as classes dominantes, forçando-as a demonstrar apoio ao movimento que já se tornava épico para os padrões do sul da Bahia.

Os ferroviários e demais participantes das atividades do movimento grevista retornaram à Sociedade Montepio às 20h. Àquela altura, as notícias de que a empresa ferroviária havia aceitado um acordo já circulavam. Enquanto ocorriam as atividades da caravana em Itabuna, os chefes da EFIC negociavam com o intendente Mário Pessoa e os líderes da comissão grevista para chegar a um consenso. Pela tarde, o telegrama do superintendente Hull comunicando concordância com as

47 Pequeno Jornal, Ilhéus, 30 maio 1927, ano III, n. 242, p. 1-2. IGHB.

48 LIVRO de álbum social da SMPAI, 28 de maio de 1927, f. 56-57. Arquivo da Sociedade Monte Pio dos Artistas de Itabuna (ASMPAI). 
reivindicações dos paredistas foi recebido pelos manifestantes na cidade vizinha. Ainda pela noite, na sede da SMPAI houve manifestações de regozijo pela greve vitoriosa. O tipógrafo Eustáquio Bispo, por exemplo, disse que "num atrito entre os interesses de brasileiros e ingleses, venceu, felizmente, o pavilhão auriverde venceram os brasileiros e, ao terminar, ergueu um viva aos ferroviários em nome dos tipógrafos". ${ }^{49}$ Esta foi uma das poucas falas registradas em detalhe na ata, mas é um registro sintomático de que interesses de classe do operariado estiveram conjugados com valores nacionalistas e de como a greve promoveu laços de solidariedade que envolveu diferentes categorias do meio operário.

\section{O fim da greve: os ferroviários e suas comemorações no paternalismo da República oligárquica}

As comemorações continuaram pelo dia seguinte, 29, domingo, em llhéus. Os ex-grevistas retornaram à cidade às $18 \mathrm{~h}$, onde foram recebidos por ajuntamento reunido na Praça Cel. Pessoa, acompanhados da banda Euterpe Itabunense e dos diretores da União Protetora, da Associação dos Empregados no Comércio, da União dos Estivadores e da Sociedade Montepio de Itabuna. Em cortejo, os trabalhadores fizeram trajeto até a casa do intendente Mário Pessoa e, de lá, para as sedes da Protetora e dos Estivadores. A imprensa de Salvador estimou que cerca de duas mil pessoas estivessem presentes nas comemorações. ${ }^{50}$ Com a greve vitoriosa, não faltou quem quisesse levar os créditos políticos da vitória dos ferroviários. Por isso, à frente da residência do intendente, o farmacêutico Joaquim Lopes Filho agradeceu em nome dos empregados da State ao chefe da comuna os "bons ofícios para terminação da greve" e disse que Pessoa havia sido "integralmente favorável às suas aspirações". Comportamento semelhante teve Nelson Schaun, que, além de fazer render reiteradas homenagens ao prefeito da cidade, arrogou, no Correio de Ilhéus, ter sido "líder do movimento grevista". 51

Não é estranho que os chefes políticos quisessem angariar os louros da vitória do movimento grevista no sul da Bahia. Aldrin Castellucci afirma que as facções oligárquicas trataram a grande greve de 1919 em Salvador como "um movimento justo, legítimo e pacífico", pois vislumbravam a possibilidade de contar com o apoio

49 LIVRO de álbum social da SMPAI, 28 de maio de 1927, f. 59. Arquivo da Sociedade Monte Pio dos Artistas de Itabuna (ASMPAI)

50 Diário da Bahia, Salvador, 31 maio 1927, ano LXXII, n. 124, p. 1. BPEB. Também Fontes aponta a mesma notícia. FONTES, op. cit., p. 215.

51 Correio de Ilhéus, Ilhéus, 31 maio 1927, ano VII, n. 898, p. 2. APMIJM. 
da classe operária em tempos de eleição. ${ }^{52}$ Em acréscimo, para o historiador Luciano Guimarães, a preocupação das autoridades políticas quanto ao envolvimento do operariado com as "ideias perniciosas" é como a preocupação das classes dominantes com o socialismo e o anarquismo. ${ }^{53} \mathrm{Em}$ llhéus, esses dois fatores devem ter se combinado, pois a postura de cordialidade e de solidariedade refletia os interesses de manter o movimento dentro dos limites da ordem e da lei apreciados pela vontade senhorial.

O envolvimento dos chefes das oligarquias com a luta dos ferroviários ocorria no campo de um paternalismo que pretendia controlar os passos do movimento associativo e evitar sua radicalização. O uso político pós-greve refletia a preocupação de garantir que a vitória da greve não rendesse apenas aumento de salário para os trabalhadores, mas também votos e gratidão conformados numa política de coexistência e reciprocidade. Igualmente os grevistas sabiam em que terreno político atuavam, como se nota no agradecimento publicado na imprensa dias após o término da parede.

A comissão central dos grevistas da Estrada de Ferro de llhéus a Conquista vem de público, agradecer penhorada, em nome dos seus colegas de movimento, o apoio e solidariedade do povo desta cidade e do de Itabuna, especialmente o Srs. Drs. Mário Pessoa da Costa e Silva e cel. Henrique Alves dos Reis, chefes dos governos municipais, "Associação Comercial de Ilhéus", "Associação Comercial de Itabuna", "União Protetora dos Artistas e Operários em llhéus", "Monte Pio dos Artistas de Itabuna", União dos Estivadores, "Associação dos Empregados no Comércio", "Liga de Desportos Terrestres" e todos os clubes desportivos de Ilhéus, "Euterpe 3 de maio", "Euterpe Itabunense" pela ação decisiva que tiveram ao lado dos reclamantes, no momento difícil que atravessaram.

À imprensa das duas progressistas cidades hipotecaram, também, o seu eterno reconhecimento, pelo desassombro com que tomou peito a causa dos oprimidos.

A todos à imorredoura gratidão dos ferroviários da "State".

llhéus, 14 de junho de 1927.

Teodoro Santos, Cantídio Oliveira, Achilau Oliveira, Lisandro Melquíades, José Vitorino, Francisco Ferreira, José Cerqueira Lima, Ubaldino Oliveira, Deobindo Neves e Agrário Nunes. ${ }^{54}$

52 CASTELLUCCI, Aldrin A S. Industriais e operários numa conjuntura de crise (1914-1921). Salvador: FIEB, 2004. p. 220.

53 GUIMARÃES, Luciano de Moura. Ideias perniciosas do anarquismo na Bahia: lutas e organizações dos trabalhadores da construção civil (Salvador, 1919-1922). 2012. Dissertação (Mestrado em História) - Universidade Federal da Bahia, Salvador, 2012. Conferir principalmente o capítulo II, quando o autor aborda as organizações operárias do sindicalismo revolucionário baiano e a preocupação dos chefes políticos com a disseminação de ideias anarquistas.

54 Pequeno Jornal, Ilhéus, 17 jun. 1927, ano 3, n. 248, p. 2. IGHB. 
Agradecer às autoridades políticas e aos demais chefes talvez fizesse parte do ritual de deferências de um grupo subalterno que joga no campo das classes dominantes para valorizar suas próprias conquistas. Usar a retórica da cordialidade e do agradecimento era uma mostra da capacidade que os ferroviários tinham de enaltecerem sua greve vitoriosa nas brechas das relações de forças com as classes dominantes. Foi a maior paralisação operária do sul da Bahia na Primeira República de que se tem notícia. Mobilizou não apenas os empregados da Estrada de Ferro, mas conseguiu criar uma esteira de solidariedade que congregou a pluralidade dos trabalhadores (artistas, caixeiros, estivadores, carregadores etc.) e que extrapolou as barreiras regionais, haja vista a participação dos colegas de Salvador nos primeiros dias da greve. Por sinal, na capital da Bahia, a greve da Este Brasileiro também foi encerrada com a vitória dos ferroviários em 27 de maio. ${ }^{55}$

O que a greve dos ferroviários da State em 1927 nos oferece de importante é o fato de que ela ocorreu ao final da Primeira República e no sul da Bahia, contextos que são reconhecidos pelo autoritarismo e pelo mandonismo das oligarquias. De acordo com uma historiografia mais tradicional do coronelismo no sul da Bahia, o advento de uma paralisação de operário jamais levaria em consideração uma postura de negociação e de conciliação com intendentes e chefes políticos locais. Pior ainda, talvez esta seja uma greve praticamente desconhecida, pois o conceito de coronelismo como expressão de poder das classes dominantes locais inibiu qualquer protagonismo dos trabalhadores, estes tomados frequentemente como passivos, inapetentes e inaptos aos modos de dominação. ${ }^{56}$

A greve dos ferroviários de 1927 nos permite compreender que mecanismos de astúcia e de leitura política foram empreendidos para a maior e a mais vitoriosa mobilização grevista de trabalhadores do sul da Bahia. Ao buscar a interlocução de intendentes, de negociantes comerciais e de intelectuais com vínculos nos círculos operários de llhéus, os paredistas comprometeram taticamente os poderosos com seus "sagrados interesses". Mais do que isso, reverteram a funcionalidade mesmo de um paternalismo senhorial que desejava controlá-los, porque talvez desconfiassem do seu potencial de subversão e rebeldia. Mantendo-se mobilizados nos limites da ordem e de acordo com os valores morais das classes dominantes, os

55 FONTES, op. cit., p. 213-215.

56 Há uma historiografia do coronelismo e da I República que ao afirmar os modos de dominação das oligarquias baianas, anulam qualquer possibilidade de agência dos trabalhadores, classificando-os como analfabetos, alienados ou incapazes de reagir à exploração ou à opressão. Conferir alguns exemplos disso: LINS, Wilson. Mandonismo e obediência. In: LINS, Wilson. Coronéis e oligarquias. Salvador: Ianamá, 1988; FALCON, Gustavo. Os coronéis do cacau. Salvador: Centro Editorial da UFBA; lanamá, 1995; PANG, Eul Soo. Coronelismo e oligarquias1889-1930: a Bahia na Primeira República brasileira. Rio de Janeiro: Civilização Brasileira, 1979. 
ferroviários encontraram uma brecha por dentro dos espaços institucionais de poder contra os patrões e em favor de seus interesses. Escreveram para deputados federais, reuniram-se com o intendente municipal, pressionaram a Associação Comercial, agindo calculadamente para que noções de patriotismo se convertessem em pressão contra os administradores da ferrovia. Habilmente conseguiram fugir da costumeira repressão policial, sempre à espreita, apesar da postura pacífica do movimento. Talvez uma opção pela radicalização trouxesse contornos mais dramáticos para a conquista do aumento dos salários. ${ }^{57}$

Em suma, pode-se dizer que os ferroviários optaram por ações mais negociadoras de construir sua greve, pois sabiam também que comprometeriam as autoridades a terem que resolver o impasse da negociação com os chefes da ferrovia antes que o movimento se radicalizasse. Por outro lado, diante de um contingente operário organizado, parcialmente instruído - pois vários sabiam ler e escrever - e mobilizado por suas "justas aspirações", políticos e dirigentes sabiam que a tolerância e o apoio poderiam lhes render bons resultados eleitorais e de dominação. Sabiam que se tratava de operários com proeminente atuação coletiva por meio de suas associações mutualistas, diante do que a adoção de posturas intransigentes ou o uso da repressão policial a priori seriam inadequados ${ }^{58}$. Como afirma Elias ${ }^{59}$, envolvidos numa teia de pressão social, os poderosos equilibram tensões e conflitos de interesses a partir de funcional relação de dependência com seus subalternos, de forma a garantir a redes de poder, de clientelismo e de economia de favores. Não foi por acaso que os intendentes de Ilhéus Mario Pessoa e de Itabuna Cel Henrique Alves se mostraram tão compreensivos quando viram os ferroviários entrarem em greve.

57 Há aqui uma astúcia dos ferroviários ao posicionar o movimento grevista no interior do coronelismo e da política oligárquica baiana. Na posição de subalternos, eles rogaram em gratidão à interlocução dos poderosos e intelectuais, porque conheciam e manipulavam bem os valores do paternalismo senhorial, a ponto de revertê-los em favor do movimento grevista diante do impasse com os chefes da ferrovia. Parafraseando Sidney Chalhoub, cada funcionário da The State sabia bem que parte das esperanças da vitória da greve dependia do tipo de relacionamento que mantinha com as autoridades políticas. CHALHOUB, Sidney. Machado de Assis: historiador. São Paulo: Companhia das Letras, 2003. p. 51.

58 Ao analisar a mediação de prefeitos nas negociações dos grevistas com os chefes da ferrovia, lembramos aqui de como Thompson analisava a atitude permissiva da gentry para com as turbulências e os motins populares na Inglaterra. Precaução e delicadeza para cuidar da insatisfação dos de baixos, especialmente quando estes têm potencial de rebeldia e subversão, torna-se a melhor forma de evitar cenários de conflito acirrado e de ameaças da ordem social. Em seu proveito, prefeitos e chefes oligárquicos realçavam sua autoridade, encenavam sua tolerância com os protestos com vistas a reforçar seu lugar de mando no jogo do paternalismo. Cf. THOMPSON, E. P. As peculiaridades dos ingleses e outros artigos. Campinas: Ed. da Unicamp, 2001. p. 222-224.

59 Reflexão inspiradas em Nobert Elias. Em seu estudo sobre as cortes europeias, ele considerou que mesmo os reis e os príncipes das nobrezas estavam inscritos numa rede de pressão constante dos seus súditos. O poder que se afigurava absoluto, em verdade, era regulado por uma política de dependência e reciprocidade que equilibrava os desígnios de indivíduos e de grupos diversos na sociedade. Esta avaliação se acomoda na reflexão sobre os laços que atavam chefes do coronelismo e os trabalhadores dos grêmios. Cf. ELIAS, Nobert. A sociedade de corte: investigação sobre a sociologia da realeza e a aristocracia da corte. Rio de Janeiro: Jorge Zahar Editor, 2001, p. 50-51. 
Convém analisar os modos pelos quais as associações operárias desenharam formas de atuação consideradas aceitáveis na defesa de seus interesses de classe frente a patrões e governantes. Adular o ego paternalista das autoridades e dos patrões era uma forma de preservar a chama - nem sempre ardente - da atitude e da coragem. Aliás, se não adotavam formas de lutas tradicionais do anarquismo e do socialismo revolucionário, os ferroviários da União Protetora de llhéus mostraram seu empenho em enfrentar a intransigência dos patrões ingleses. A questão da identidade nacional foi um traço importante para que a greve ganhasse a solidariedade da população em geral. Como afirma Alexandre Fortes, não é somente a legitimidade e a justiça das suas causas que levam os trabalhadores a optarem por uma certa forma de luta, mas sim uma ação coletiva capaz de agregar diferentes sujeitos e sentimentos em apoio às campanhas de reivindicação. ${ }^{60} \mathrm{Sem}$ desafiar a autoridade policial e sem perturbar a ordem pública, eles paralisaram por completo a Estrada de Ferro e conseguiram, por dentro da rede de poder, desfraldar seus "sagrados interesses".

Recebido em 29/07/2019

Aprovado em 23/10/2019

60 FORTES, Alexandre. Nós do quarto distrito...: a classe trabalhadora porto-alegrense e a Era Vargas. Porto Alegre: Garamond, 2004, p. 269-270. 